\title{
Intermedialitás Bret Easton Ellis Glamoráma című regényében
}

\begin{abstract}
Molnár Bálint
Intermediality in Bret Easton Ellis's Glamorama

Abstract

This paper aims to examine Bret Easton Ellis's novel titled Glamorama in terms of intermediality. The first part of this work discusses the fusion of the fictive world depicted in the novel, the narrative levels and the cinematographic instruments. Subsequently, it deals with its screenplay-like narrative. Afterwards, it introduces the medialized world, the swap of mediality and reality, the question of the imaginary and real as well as way the cinematic narration works. In addition, the analysis points out the separation of the camera and the protagonist's position as well as the separation of the narrative and the viewpoint. The paper emphasizes that the intermedial elements mean the imitation of the original media rather than their involvement. Finally, the examination focuses on the functioning of the film as a medium within the text. The visual and acoustic elements are identified, too.
\end{abstract}

Keywords: intermediality; postmodern; MTV-generation; medium

Kulcsszavak: intermedialitás; posztmodern; MTV-generáció; médium

Subject-Affiliation in New CEEOL: Language and Literature - Studies of Literature - Other Language Literature

DOI: 10.36007/eruedu.2021.2.67-80

1998-ban jelent meg Bret Easton Ellis várva várt regénye, a Glamoráma. Nyolc éven át, 1989 decemberétöl 1997 decemberéig dolgozott rajta a szerző, aminek meg is lett az eredménye: ez lett az egyik legösszetettebb, szövegszerkezetileg a legkomplexebb alkotása. Nem szabad azonban meglepödnünk ezen, ugyanis várható volt, hogy az előző regényekben megkezdett eljárások elöbb-utóbb a csúcsra érnek. Az az idő, amire Ellisnek szüksége volt ahhoz, hogy megírja ezt a könyvét, a terjedelemben is megmutatkozik: a Holdpark megjelenéséig Ellis minden regénye hosszabb volt, mint az azt megelőző müve, ez alól a Glamoráma sem kivétel. A szerző korábbi regényeiben is fellelhetö az a törekvés, amely a Glamoráma egyik kulcsmomentumává válik: a valóság és a fikció határain való egyensúlyozás, mégpedig oly módon, hogy a létezőnek vélt világot „,médiaintervenciók” egész sorával, valamint hamis képek reprodukciójával próbálja konstruálni, mely nagyban hozzájá- 
rul az identitásképző elemek reprezentálásához is. A regényben megjelenő forgatások egymást szövik át úgy, hogy egy végtelennek tünő tükörtermet tárnak elénk, ahol nemcsak a valóság, de a fiktív világ is többszörösen megkérdőjeleződik. S hogy mindez ne legyen elég, olyan érdekes szövegjelenségek tanúi is lehetünk, melyek gyakran túlmutatnak a „hagyományos regény” fogalmán. Az egyik ilyen izgalmas játék például az, amikor a könyvben szereplő filmforgató stáb „átveszi” az irányitást, majd a főszereplő a rendező utasításait kezdi el követni, elbeszélései pedig már-már a forgatókönyvszerüség határait súrolják, ezzel összemosva minden addig általunk vélt stabil pozíciót. A regény a modern celebkultúra szatírája is egyben, melyet jól tükröz a modellek terroristává alakulása is. A kép és a látvány által uralt kultúrában minden megszünik, ami hiteles vagy valószerü, és átveszi a helyét az egyre népszerübb mesterkélt világ.

Nem elhanyagolható az sem, hogy a szerző ebben a regényében már a cselekménynek is teret adott, a történet- és karakterfejlődés pedig egyértelmü váltás Ellis korábbi elbeszélői stílusához képest. A Glamoráma szereplői színészek, modellek és hírességek. A föhős, Victor Ward és társai egy olyan társadalmi csoportba tartoznak, ahol a média által vezérelt képek és a kamerák által rögzített jelenetek válnak a valósnak vélt világ mozgatórugóivá. Ahogy a Glamoráma története halad elöre, úgy azonosul egyre több szereplő a hallucinált képek sokaságával, egyre inkább elfeledve azt, hogy kik is ők valójában. A fiktív világot tehát Victor számára a médiumok által közvetített képek formálják. Ez a látványvilág folyamatosan konstruálja, dekonstruálja és rekonstruálja Victor identitását, miközben szünet nélkül mozog az egyes szerepek között: szupermodellt és klubtulajdonost, vagy épp egy „híres filmsztárt” alakít. A regényben Victor a termékek és a kapcsolatok fogyasztójaként egyaránt megjelenik, miközben saját maga fogyasztójává is válik.

Jelen tanulmány a Glamoráma elemzésére vállalkozik az intermedialitás kérdésének vonala mentén. Tudjuk, hogy az irodalmi mü nem monomediális, ami azt jelenti, hogy más médiumokkal is együttmüködik. Tehát az irodalmi szövegek és az azon belül fellelhető nyelvi jelek más-más médiumokkal (pl. vizuális, akusztikai) állnak szoros kapcsolatban - sokszor attól függően, hogy épp melyiket kivánják játékba hozni. A Glamoráma így a regény médiumán keresztül további médiumokat is megidéz és játékba hoz. Nagyon fontos hangsúlyozni ugyanakkor, hogy az intermediális effektusok nem az eredeti médiumok bevonását jelentik, hanem azok imitációját (Fodor - L. Varga 2012, 176). Az intermedialitás definíciójával kapcsolatban Rajewsky így fogalmaz: „az adott médiatermék egy másik, konvencionálisan eltérő médium elemeit vagy struktúráit tematizálja, idézi vagy imitálja saját médiaspecifikus eszközeinek felhasználásával" (Rajewsky 2005, 53). Érdemes azonban szétválasztanunk ezt a kijelentést és külön tárgyalni a benne említett mozzanatokat, ugyanis az intermedialitásnak több módozata van aszerint, hogy a kapcsolt médiumok milyen viszonyban vannak egymással.

Az egyik leggyakoribb módja tehát az, amikor az egyik médium tematizálódik a másikban, vagyis magában az irodalmi szövegben felhalmozódnak az egyes médiumok. A másik változat - és a számunkra lényegesebb - viszont az a jelenség, amikor egy médium egy másik médiumon hagyja a nyomát, amikor bevonja a másik médium valamilyen tulajdonságát, illetve imitálja azt, vagy éppen reflektál a mediá- 
lis különbségekre. Ellisnél ez leginkább a kliptechnikában (Nullánál is kevesebb, Amerikai Psycho), valamint a forgatókönyvszerüségben és a film médiumának megidézésében (Glamoráma) nyilvánul meg.

Fodor Péter és L. Varga Péter közös alkotása, Az eltünés könyvei kiváló kiindulási alapot ad az intermediális jellegü vizsgálódáshoz (is), így nem véletlen, hogy jelen tanulmány is ezt a monográfiát tekinti legföbb támaszának. A médiumok közötti átjárhatóság, valamint ennek funkciói döntően befolyásolják Ellis posztmodernhez füződő viszonyát, melyre izgalmas válaszként szolgálhat a Glamoráma, különösen akkor, ha a regényben bemutatott mediatizált társadalmat a könyv és a film médiumán keresztül a megfelelö kontextusba helyezzük.

\section{A Glamoráma az elődei kontextusában}

Általánosságban elmondható, hogy az intermedialitás bizonyos formái Bret Easton Ellis összes regényében fellelhetők. A legelső könyve például, a Nullánál is kevesebb MTV-regényként maradt meg a köztudatban, hiszen Ellis kifejezetten jól importálta könyvébe a zenecsatorna különböző technikáit: a rövid, pergő, töredékes, videoklipre hasonlító fejezeteket és a montázsszerű képalkotásokat. A kétszáznyolc oldalas regény száznyolc nagyon rövid fejezetböl áll, mely kellöképpen tükrözi az MTV-videók sebességét, folyamatos áramlását.

A 24 órás műsoridővel rendelkező csatornát szintén rövid, egymáshoz nem kapcsolódó klipek alkotják, melyet csak a reklámok és interjúk szakítanak meg. Az MTV állandó jelenléte nemcsak a regény felépítésében játszik fontos szerepet, hanem a föhős és társai történetének elengedhetetlen kíséröjévé is válik. Az intermedialitás Ellis első regényében leginkább úgy müködik, hogy a vizuális kép és a zenék, dalok nyelvét átalakítja rövid (akár egy-két szavas) mondatokká úgy, hogy azok a lehetö legjobb hatást keltsék (Baelo-Allué 2007, 155).

Az Amerikai Psychóban már jóval tovább megy Ellis a mediális technikák alkalmazása terén (is). Patrick Bateman, a regény sorozatgyilkosa gyakran a reklámok, bulvárlapok, dalok és filmek nyelvén írja le a történéseket. Az MTV mellé ugyanolyan fontos alkotóelemként társul a Patty Winters Show, a regény cselekményének nyelvi ábrázolásához pedig sokszor filmes szakkifejezéseket használ, kölcsönöz: „Lassú áttűnés, és máris azt látjuk, hogy Price szökellve fut fel az elegáns kis műemlék ház lépcsőjén..." (Ellis 2016a, 17). Eredeti megfogalmazásban még inkább hatásosak ezek az elemek: „Like a smash cut from a horror movie - a jump zoom” (Ellis 1991, 292), „Smash cut and I'm back in the kitchen” (Ellis 1991, 11). Tudjuk, hogy Bateman a regény fiktív világában a cselekményt, a történéseket filmként kezeli, vagy annak képzeli el. Ezeknél a jeleneteknél azonban láthatjuk, hogy itt nem pusztán erröl van szó, hanem sokkal inkább arról, hogy a fiktív valóságot már filmes eszközökkel is szemlélteti. A hangsúly itt tehát azon van, hogy az Amerikai Psychóban a filmes elemek alkalmazása nemcsak a főszereplő fantáziáját elégíti ki, hanem az elbeszélő szemszögéböl történő fiktív valóság leírására is szolgál.

A jelenetek filmszerüségére és a lehetséges forgatásokra, stábokra való utalások az Amerikai Psychóban már egyre többször jelen vannak, mégis a Glamorámában 
teljesednek ki leginkább. Ellis ebben a regényében a hangsúlyt a fogyasztói társadalomról áthelyezi a szubjektum és a kép által uralt kultúra dilemmáira (Colby 2011, 97). Írott szavak, vizuális képek és akusztikus referenciák építik a főhős, Victor világát. Ezek az intermediális referenciák a Glamorámában a médiumok termékei, és amellett, hogy állandóan változó, felszínes diskurzusokat idéznek meg, rámutatnak e médiumok manipulatív, szelektív és torzító jellegére is (Fodor - L. Varga 2012, 164).

A valós és az imaginárius kérdése, ami már Ellis első regényében megjelent és az Amerikai Psychóban tovább erősödött, a Glamorámában éri el csúcspontját. A regény első részében az intermediális utalások kiemelt hangsúlyt kapnak, hiszen létrehoznak egy olyan speciális kontextust, melyben a képek nemcsak helyettesíteni próbáljak, hanem meg is alapozzák a fiktív valóságot az elbeszélésben. A nyomtatott, az akusztikai és a vizuális médiumok referenciái alkotják meg a karaktert, a beállítást és a témát (Baelo-Allué 2011, 86). A magazinok, fotók, videók és dalok kulcsfontosságú elemek egy olyan világban, ahol a hírességek médiaképük révén építik fel önmagukat. A kamerák és a különböző filmes stábok állandó jelenléte már a regény első felében olyan eseményeket hoz létre, melyek elmossák a valóság és a fikció közötti határokat. Ellentétben Ellis korábbi regényeivel, ez a kettősség nem állandósul, hanem fejezetröl fejezetre egyre fokozódik, az egész regény során folyamatosan növekszik a két szint közötti ingadozás. A továbbiakban néhány példán keresztül láthatjuk, hogy müködik ez a gyakorlatban.

A Glamoráma története úgy indul, hogy Victor mellé egy riporter szegődik, akinek az a feladata, hogy ,,mindenhová kövesse öt egy héten át” (Ellis 2016b, 14). Itt eszünkbe juthat, hogy a Nullánál is kevesebb föszereplőjét, Clayt is követte egy fotós. Már rögtön a regény elején, amikor Victor megkérdezi az őt követő riportert, hogy mit gondol a pettyekről, meglehetősen félreérthető választ kap: „Nem hiszem, hogy része lennék a sztorinak" (Ellis 2016b, 15).

A fiktív valóságon belül ezt az állítást egyrészt úgy lehetne értelmezni, hogy a riportert egyáltalán nem érdekli sem Victor, sem a problémái a pettyekkel, másrészt pedig akár metafiktív utalás is lehet arra nézve, hogy ő nem ehhez a narratív szinthez tartozik. A regényben megjelenő fiktív világ és az arról készült felvételek összemosódnak, mely elöször akkor figyelhetö meg, amikor a „,videokamerás srác” nézőpontjából írja le Victor az eseményeket: azt látjuk, ami Victort érdekli, de a kamera objektívén keresztül (Ellis 2016b, 21). Nem sokkal később Victor barátnőjének a lakását a következő szavakkal írja le: „Pillanatkép Chloe lakásából (a belső teret mintha Dan Flavin tervezte volna)" (Ellis 2016b, 62). Ugyanúgy, mint az Amerikai Psychóban, a szerző itt is filmes terminust használ, hogy a vizuális jellegü környezetet integrálja a szöveg nyelvébe. Amikor Victor a konditeremben van, először válik egyértelművé, hogy egy filmes stáb is jelen van: az edzőjét filmezik, hírességekről szóló anyagot forgatnak, paradox módon „olyanokról, akik híresebbek, mint a hírességek, akiket edzenek" (Ellis 2016b, 83). Victor és edzője, Reed úgy beszélgetnek egymással, mintha teljesen egyedül lennének a teremben, ugyanakkor időközönként megszólal a rendező és utasításokat ad, melyek úgy integrálódnak a dialógusokba, mintha az Victor és Reed párbeszédének a része lenne. Ez létrehozza Victor valós élete és az erről az életről szóló dokumentumfilm közötti tökéletes egyveleget. 
Általánosságban elmondható, hogy Victor a regényen belüli fiktív valóságban túlnyomórészt kamerák és riporterek kereszttüzében mozog. Minél inkább közelebb kerülünk a regény első fejezetének végéhez, egyre világosabbá válik, hogy Victort nemcsak néha, hanem állandóan filmezik. Úgy tűnik, hogy az egész élete a létezésének a dokumentálásáról szól: az operatör váratlan felbukkanásai, a rejtett rendezői utasitások, a filmes kellékek és szakszavak, a forgatókönyvszerü elbeszélés is csak megerősíti mindezt. A szövegböl továbbá az is kiderül, hogy más embereket is követnek, más karaktereket is állandóan filmes stábok vesznek körül.

A történet elörehaladtával Victornak feltünik, hogy az utcákon a rengeteg filmforgatás miatt szinte lehetetlen közlekedni (Ellis 2016b, 195). Az egész odáig fajul, hogy már a filmes stábot is filmezik. Az egyik jelenetben, amikor Victor lakásán az MTV interjút készit vele, arról tájékoztat hősünk, hogy egy japán srác filmezi az interjút, egy másik japán srác pedig fényképeket is készit róla (Ellis 2016b, 200). Így aztán nem meglepő, hogy egyre inkább eldönthetetlen a valóság és fikció kérdése, a könyvön belüli film és a filmen belüli film, illetve a könyvön belüli forgatókönyvek szerepe.

Victor dialógusaiban nagyon sokszor jelenik meg egy-egy dalszöveg vagy dalrészlet, illetve reklámszöveg. Erre a késöbbiekben a jelen tanulmány bövebb kitéröt tesz, ezek az utalások ugyanis Ellis összes regényében fontosak, nemcsak abban az értelemben, hogy felépítésüket átülteti az elbeszélésbe, hanem azért is, mert a zenei élmény mellett meghatározzák a szereplök szókincsét és identitását, valamint jelentős szerepet játszanak az értelmezésben. Baelo-Allué szerint annak ellenére, hogy ezek az intermediális referenciák határozzák meg a szöveg hitelességét, felerősítik a valóság és fikció dilemmáját, destabilizálják a karaktert és a cselekményt, egy dolog állandó marad: Victor marad az elbeszélő, az ő nézőpontjából férünk hozzá az információkhoz (Baelo-Allué 2011, 87). Ezt viszont érdemes annyival kiegészíteni, hogy ez az állítás kizárólag a regény első fejezetére érvényes, ugyanis látni fogjuk, hogy a beszédhelyzet és a nézőpont a regény számos pontján élesen elkülönül, később pedig Victor hasonmása is megjelenik, aki szintén felveszi az elbeszélő pozícióját.

\section{A mozi/próza dilemma}

A regény elörehaladtával az intermediális referenciák felerösödnek, beárnyékolják Victor nézőpontját és fokozatosan destabilizálják nemcsak a karaktert, hanem az elbeszélést is. A Glamoráma második fejezetétől kezdődően a narráció szinte teljesen filmszerűvé válik. Ezt Ellis úgy hozza létre, hogy meghatározott filmeffektusok imitációjához folyamodik, mint például a különféle vágások és jelzések, rendezői utasitások, filmzenék, montázs, rögzített képek és kellékek, melyek mind megerösitik elbeszélésének vizuális nyelvét. Metafiktív eszközei arra késztetik az olvasót, hogy megkérdőjelezze a narratív konstrukciók valóságát, ami tovább fokozza a posztmodern ürességet. A vágás folyamata is hangsúlyossá válik, gyakran vágnak ki vagy alakítanak át montázzsá egy-egy jelenetet. A filmes utalások és eszközök fokozatosan épülnek bele a szövegbe, „,megteremtve ezzel a kellő bizonytalanságot 
annak eldönthetőségére nézve, mi történik képen kívül és belül, hol a keret egyáltalán és mennyi van belöle" (Deisler 2018, 133).

A történet akkor lép át teljesen a film világába, amikor Victor felszáll a Queen Elizabeth 2 fedélzetére. A narrátor megerősíti ezt a kamera átpozicionálásával és a föhős filmszínésszé alakításával:

\begin{abstract}
Olykor összejött a stáb, és a kamera diszkrét távolságból követett, a legtöbbször a felső fedélzet jobb oldali korlátjánál álltam, próbáltam rágyújtani, és néha marihuánás volt a cigi, néha nem, a napszemüveg a szememen, és Armani bördzseki volt rajtam, pár számmal nagyobb a kelleténél. Azt mondták, nézzek szomorúan, úgy, mintha hiányozna Lauren Hynde, és mintha megbántam volna, ahogy Chloéval bántam, meg mintha széthullana a világom. Biztattak, hogy próbáljam megkeresni Laurent Miamiban, ahová elment Damiennel, és megadták egy híres szálloda nevét is, de én tengeribetegnek tettettem magam, és ezeket a jeleneteket kidobták, mert semmilyen módon nem paszszoltak a karakteremhez (Ellis 2016b, 274).
\end{abstract}

Jól látható, hogy hősünk kettős valóságban, két fiktiv cselekményben él: a Glamoráma által felépített valóságban és az azon belüli fiktív film által konstruált valóságban. Úgy is mondhatnánk, hogy a kamera két képre osztja Victor elbeszélését: az első az, amelyik a fiktív forgatócsoport kameráit mutatja, míg a másik az, amit maga a kamera rögzit. Ez a két kép lebeg a történetek felett, lehetővé téve azt, hogy a narratív szintek között barangoljunk. A kamera tehát rendkívül fontos szerepet tölt be a szövegben, ráadásul közeli képei Victor arcáról, modoráról, lépéseiröl fokozzák az olvasásélményt és manipulálják a befogadást. Victor premier plánba esetenként szuper plánba - hozatalával Ellis egy vizuális kettősséget alkot a föhősröl, mely sokszor ellentétet produkál Victor érzései és a valós cselekedeti között.

A regény második részében a stáb, aki Victort kíséri, fokozatosan épül be a történetbe, és állandó résztvevőjévé válik. Míg a kamera az első részben csak a megfigyelő szerepét töltötte be, addig a másodikban már alakot is ölt: Felixként jelenik meg az operatör és fontos karakterré alakul. Egy alkalommal Victor a QE2 egyik bárjában Felixtől számos háttérinformációt megtud a forgatókönyvröl, többek között azt, hogy nincs is befejezve, hogy valószínüleg menet közben találják majd ki (Ellis 2016b, 277). Amikor Victor ezek után azon gondolkodik, hogy miként tudná a legjobban megformálni a saját karakterét, arra gondolhat az olvasó, hogy a Glamoráma akár egy olyan szövegként is müködik, ahol maga a regényírás folyamata épül be a cselekménybe. Ahol a forgatókönyvíró és a rendezö felügyeli az írás folyamatát, a cselekmény felépitését pedig integrálják a szövegbe, mintha ök maguk lennének a történet szerzői, vagy ahogy Molnár Gábor Tamás is fogalmaz: „a megjelenített rendező akár Ellisnek, a regényírónak az alteregója is lehet” (Molnár 2005, 131). Érdekes az a mozzanat is, amikor Victor London helyett Párizsba veszi az irányt: ez szimbolikusan ugyan, de akár úgy is értelmezhető, hogy a karakter veszi fel a szerző szerepét, és „,saját életet” kezd el élni. Vagy amikor Felix, az operatör bizalmasan közli Victorral, hogy Palakon nem szerepel a forgatókönyvben (Ellis 2016b, 329), akár azt is jelenthetné, hogy a „szerzőnek” menet közben új ötlete támadt, ami eredetileg még nem szerepelt a cselekményben. 
A második fejezetben kibontakozó filmtörténet így tulajdonképpen beleavatkozik Victor első fejezetben bemutatott glamourközegébe. Létrejön egy szerteágazó elbeszélés, melyben elmosódnak azok a pillanatfelvételek, amelyeket Victor a kamerán keresztül tapasztal, felfedvén így a reprezentációs káoszt. A forgatókönyv központi helyet foglal el a narrativában, és folyamatosan utalnak a tartalmára. Felix, a fiktív operatőr szavai figyelmeztetik Victort a szövegkönyv apró betűs részére: „Nem olvastad a forgatókönyv többi részét? [...] Nem tudod, mi fog történni veled? [...] Csak légy felkészülve - mondta Felix. - Fel kell hogy legyél készülve. [...] Nagyon kell hogy figyeljél' (Ellis 2016b, 276-277). Ez a figyelmeztetés tulajdonképpen utalás is lehet az elbeszélés rétegzettségére, a valóság többrétegü befogadására, ami igazából az egész szövegre jellemző. A regény elörehaladtával az elbeszélés és a forgatókönyv közötti kapcsolat egyre szorosabbá válik. Sem az olvasó, sem az elbeszélő nem tud különbséget tenni a két szint között. Erre kiváló példa az a pont, amikor Victor egy pillantást vet a kéziratra, és ezáltal a későbbi történésekre is:

Egy forgatókönyv hever a kávézóasztalon, szórakozottan felveszem, találomra kinyitom: egy furcsa jelenet az, Bobby nyugtatgat valakit, nekem meg ad egy Xanaxot, zokogok, a többiek öltözködnek egy újabb partihoz, egy sort elolvasok a dialógusból (,mi van, ha valaki olyan lett belöled, aki nem voltál"), aztán lecsukódik a szemem. Úgy képzelem, a rendezö azt suttogja a fülembe: „Aludj el.” (Ellis 2016b, 397)

Miután szemtanúja volt Sam Ho halálra kínzásának, Victor összeomlik, és a forgatókönyvben szereplö jelenetek játszódnak le: „Bobby egymás után tömi belém a Xanaxokat” (Ellis 2016b, 401), majd ezt mondja Victornak: „mi van akkor, ha egy napon átváltoztál valakivé, aki nem vagy?" (Ellis 2016b, 405). Amellett, hogy a Xanax pánikbetegségek és szorongás elleni gyógyszer (ami könnyen okoz emlékezetkiesést is), egyben palindrom is, mely kiválóan mutatja be Victor mentális állapotát és a narratív szintek elmosódását, játékba hozva többek között a Doppelgänger-effektust is. Ez utóbbi nem véletlen, hiszen az identitás megtöbbszörözése, azok határainak feloldhatósága a technikai médiumok következménye (Fodor - L. Varga 2012, 181). Kifejezetten jó példa erre már a regény első fejezetében az a jelenet is, amikor Victor a titokzatos alakkal, Palakonnal találkozik a Fashion Café nevü bárban. Itt az lesz a benyomásunk, mintha Victor be-, illetve kisétálna a jelenetböl: egy pillanatra elhagyja a kávézót, ám amikor visszajön, üres helyiséget talál. Úgy tűnik, hogy Palakon nem emlékszik Victor nevére, hol Mr. Wardnak, hol Mr. Johnsonnak szólítja, és nem egyértelmü, hogy Victor alteregóját vagy épp Victor filmes karakterét látjuk:

- Talán nem tetszett neki a forgatókönyv - vonom meg a vállam. - Talán úgy érezte, hogy nem dolgozták ki elég jól a szerepét. Előfordul az ilyesmi, apafej.

- Maga... - Palakon zavartan lenéz az aktájára - maga ezt honnan tudja? (Ellis 2016, 170)

A regény vonatkozási rendszere tehát a különböző forgatókönyvek és a forgatások egyvelegéből bontakozik ki, melyben az „elbeszélő egy számára átláthatatlan, 
többszörösen meg- és átrendezett akciószövedékbe bonyolódik" (H. Nagy 2007, 55). S amikor világossá válik, hogy Victor nem ura a tetteinek, Bobby így fogalmaz a regényben: „Nem kell megrémülnöd ezektöl. [...] Mindenre számítani lehetett. Az egész benne volt a forgatókönyvben. Semmi olyan nem történt, amin meg kellene lepödnöd" (Ellis 2016b, 403). Victor a szövegkönyv ismeretét illetöen egyáltalán „,nincs képben” - ezt a „mi a sztori?” kiszólása állandóan megerősíti. Ez azonban egyáltalán nem meglepő, hisz ez a forgatókönyv tele van melléktörténettel és epizódrészletekkel, amelyek elhomályositják a történet olvasatát és megértését. Söt, a kamera folyamatos váltása egyik forgatókönyvröl a másikra módfelett zavarja az összképet, megváltoztatja a mellékcselekményeket és a fö elbeszélést, és a kaotikus valóságba helyezi a föszereplőt. Beszédes, hogy erröl a jelenségröl még Ellis is így nyilatkozott: „Túl bonyolulttá vált. Én írtam, és még én sem tudtam többé nyomon követni" (Clarke 2004, 54).

A történet talán legkegyetlenebb része a már említett Sam Ho meggyilkolásának jelenete. Itt azonban olyasmi történik, amire korábban nem volt példa a regényben: a gyilkosságot filmező kamerán kívül semmiféle stáb vagy operatör nincs jelen (Ellis 2016b, 399-400). Később Victor saját maga eszmél rá, hogy a filmes csapat, aki állandóan kísérte őt, illetve Félix, az operatör semmit nem tud a gyilkosságról. Az a feltételezés, mely szerint Victor minden lépését a kamera követi, ennél a pontnál megdőlni látszik. Természetesen nem szabad mindent a megbízhatatlan narrációra fogni, a valós és az imaginárius problematika az egész Ellis-életmüvön végigvonul, és egyértelmű, hogy a Glamorámában csúcsosodik ki. A figyelmes (újra)olvasó azonban még ebben a szürreálisnak tünő világban is találhat kapaszkodót az elbeszélésben arra nézve, hogy lehetöséget kapjon az az olvasat is, hogy ez az egész meg sem történt, vagy ha igen, akkor a korábbi történések válnak megkérdőjelezhetővé. Még az álomvilág is többszörös tükrözödést mutat, Sam Ho meggyilkolásának fejezete ugyanis a következöképp indul:

A rövid, álomtalan alvásból hirtelen felébreszt, ahogy valaki halkan azt mondja: „Veszszük" (de mikor kinyitom a szemem és körülnézek, senki sincs ott), leszállok a diványról, és közömbösen észreveszem, hogy eltünt a forgatókönyv, amit elalvás előtt olvastam. (Ellis 2016b, 397)

Azáltal, hogy a narráció folyamatosan mozgásban tartja Victort a filmes szerepe és a valósnak vélt szerepe között, lehetetlen eldöntenünk, hogy az elbeszélés épp melyik szintjén járunk, valamint, hogy a valóság és a fikció a regényben épp melyik funkcióját tölti be. És azzal, hogy Ellis egyre több filmes csapatot sző bele a cselekménybe, akik mintha az eredeti stábok ellen (is) tevékenykednének, egy többfelé ágazó, sokféle megoldással kecsegtető cselekményt tár elénk, melyben az egyes szálak már-már egymással is versengésbe kezdenek. Így tehát nem véletlen, hogy „a dolgok megítélésében érdekelt befogadó képtelen lesz alátámasztani olvasata érvényét" (Kulcsár Szabó 2000). David Schmid szerint az olvasó azt a feladatot kapja, hogy válasszon a lehetséges értelmezések közül, amelyek mindegyikének megvan a maga következménye, és amelyek mindegyike alaposan mediatizált (Schmid 2011, 79). Ennek alapján saját következtetéseket kellene levonnunk, mi- 
vel amit Victor Ward tesz (vagy épp nem tesz), az hallucinációs tapasztalatainak következménye csupán. A mozi és a próza nyelvének fiktív összekapcsolása ennélfogva meghatározza, de ugyanakkor alá is ássa a cselekményt, illetve Victor hitelességét (Baelo-Allué 2011, 89). Így talán az sem meglepő, hogy ahogy a regény első részében bemutatott Victor modellkaraktere, úgy a később megjelenő Victor filmes performansza is kudarcot vall.

\section{Vizuális és akusztikai elemek az írott szövegben}

A filmes elbeszélés nyelvét tovább fokozza a képi montázs írott szöveggé alakitása. Egy bizonyos ideig csak a jelenet szereplőjeként közvetíti a narrátor az eseményeket, majd végül az epizódok szemlélőjévé is válik. Az elbeszélés és nézőpont ezáltal szétválasztásra kerül, ami egy olyan olvasatot produkál, melyben első ránézésre azt látjuk, hogy a főhős leír bizonyos jelenetet, melyet az ő nézőpontjából egyáltalán nem is láthatna. „Miközben az elbeszélő egyszerre alanya és tárgya az elbeszélésnek, az őt látvánnyá alakító képek és felvételek termékeként jelenik meg a szövegben" (Fodor - L. Varga 2012, 182). Jó példa erre az alábbi részlet:

\footnotetext{
Végül mégiscsak kiszabadulok, és azt motyogom, hogy mennem kell Felsö-Manhattanbe, és nagyon lezserül, mint egy igazi nagymenő, felpattanok a Vespámra, berúgom, és elsöprök a Park Avenue-n, anélkül hogy visszanéznék, pedig ha visszanézek, láthattam volna, hogy Lauren ásit, miközben leint egy taxit. (Ellis 2016b, 163-164)
}

A jelenetek mozgóképpé alakítására a következő példa is igazán szemléletes lehet. Itt már az olvasónak egyértelműen az az érzése, hogy a szereplőt egy képernyőn keresztül kíséri figyelemmel:

A Smashing Pumpkins „Disarm”-ja hangzik fel aláfestő zeneként, és egy pillanatra a klubot látjuk, amit meg akartam nyitni a TriBeCa negyedben, aztán besétálok a képbe, és nem veszem észre a fekete limuzint, ami az utca másik oldalán parkol, négy házzal lejjebb, de az operatör azt is felveszi. (Ellis 2016b, 243)

Fodor Péter és L. Varga Péter kiválóan értelmezi ezt az epizódot: „Az olvasás által kiépített jelenet látványát - akár egy filmben - montázzsá formálja (»és egy pillanatra a klubot látjuk«), majd ezt mozgóképként mediálisan érzékelhetetlen, azaz nyelvi információval egészíti ki (»amit meg akartam nyitni a TriBeCa negyedben«), kidomboritva, hogy a múltbéli eseményre történő reflexió - egyfajta nyelvi performatívumként értett flashback - kizárólag nyelvi természetü lehet. lly módon a képi montázs - mely materiális értelemben természetesen nyelvi esemény, azaz szimuláció, az írott szöveg produkciója - ugyancsak szükségszerüen utal vissza a vizuális memóriában arra, hogy a megmutatott klub csak és kizárólag az elbeszélő által megnyitni szándékozott hely" (Fodor - L. Varga 2012, 180-181). A szöveg többértelmüségének fokozása érdekében a következő példában azt észleljük, hogy nemcsak az olvasó, de a főhős is a kamerán keresztül látja saját magát: 
Külső felvétel a Hozanról. Rövid snitt rólam, ahogy odabent ebédelek, és a Christian Bale-hasonmás elsétál mellettem, de nem veszem észre, mert a közelben elhaladó géppisztolyos rendöröket figyelem, és mert elvonja a figyelmemet az elzsibbadt karom. Snittek rólam, ahogy megyek a Rue de Fourey-n a Szajna felé. (Ellis 2016b, 446)

Ebböl fakadóan fokozatos bizonytalanság alakul ki a regény során: vajon egy könyvet olvasunk egy filmforgatásról, vagy egy forgatókönyvet lapozunk? Talán egy filmet látunk, vagy nézzük, ahogy épp valakiröl filmet készitenek? Míg a regény az egyes szám első személyü narrációt használja, addig a kamera nézőpontja a filmnél a harmadik személyü narrátorénak felel meg. Az elbeszélö így egy meghasadt személyiségre hasonlít: a föhős kívülröl szemléli önmagát. Igazából persze az történik, hogy az olvasóval egyenrangú pozícióban egy szerkesztett film befogadójaként lép föl, közli velünk az akusztikai (aláfestő zene) és vizuális (felvétel a klubról, felvétel a Hozanról) elemeket, majd a filmet szemlélő pozíciójából „visszasétál a képbe”, azaz szereplői pozíciójába, valamint az utóbbi példánál már az érzékelést is játékba hozza (rendőröket figyelem, zsibbad a karom) (Fodor - L.Varga 2012, 181).

A kamera és a főszereplő pozíciójának szétválasztása, az elbeszélés és a nézőpont elkülönülése a regény negyedik fejezetétől hatványozottan felerősödik. Ellis mesteri módon lavírozik a hagyományos elbeszélöi technikák első és harmadik személyü elbeszélései között. Felmerülhet az a dilemma is, hogy bizonyos jeleneteknél a narráció a zéró fokalizáció felé veszi az irányt, például abban a részben, amikor a Boeing 747-es gép felrobbanását írja le:

Éjszaka Franciaország fölött, hatalmas árnyék, gigászi háttérfüggöny képzödik az égen, ahogy a 747-es az ötezer méterhez közeledik, kúszva felfelé az utazási magasságba. A kamera ráközelít egy légipostai csomagra - rajta egy georgetowni címmel -, amiben egy Toshiba kazettás magnó bújik meg. A szerkezet akkor aktiválódik, amikor felhangzik Paul McCartney és a Wings „1985” című dalának kezdő zongorafutama. A bomba a dalt záró harsogó cintányércsörgéskor fog felrobbanni - öt perc tizenegy másodperccel a kezdete után. (Ellis 2016b, 606)

Bár felfogható mindentudó, harmadik személyü narrátorként is, mégis valószínübb, hogy itt is az történik, mint korábban, ugyanis amit az intermediális referenciák a Glamorámában létrehoznak, tulajdonképpen egy olyan elbeszélő megidézése, aki elmondja azt, amit a képernyőn lát, vizuális elemeket idéz meg, de úgy, hogy a pozíciója az olvasóéval válik egyenrangúvá. „Az egyidejüleg két pozíciót, két látványt (és azok reflexióját) tartalmazó nyelvi közlés egyaránt inszcenírozza a képsor - a film - rögzítését és a kész produkció megtekintését, miközben a szöveg vizuális és zenei effektusok nyelvi transzpozícióját automatizálja" (Fodor - L. Varga 2012, 181).

A képi montázs és a filmes terminológia mellett a filmzene, a dalok és dalszövegek, valamint az idézetek erősítik az elbeszélés intermediális jellegét, az akusztikai elemek nyelvi transzpozícióját. A Nullánál is kevesebb jól ismert visszatérő mantrája „az emberek félnek belekeveredni”, melynek párja a Glamorámában a Victor által egy idő után folyamatosan ismételgetett „Lesiklunk a dolgok felszínén” 
idézet. Itt azonban már nem egy egyszerü kijelentésről van szó (mint Clay esetében az első regényben), hanem egy dalszövegidézetröl, nevezetesen a U2 Even Better Than the Real Thing című dalából, s mely kiválóan illeszkedik Victor popkulturális idézetfolyamába (Fodor - L. Varga 2012, 178). Míg az Amerikai Psychóban Bateman zenei „értekezései” ellentétben állnak a mindennapjaival, addig a Glamoráma éppen arra törekszik, hogy a dalok által megidézett fiktív világot és a valóság közti határt összemossa, a dalokból kivett sorokat pedig újra és újra beleszője a párbeszédekbe. Különösen a regény első részében szövi át a narráció Victor beszédét dalok idézésével. Halkan megjegyzendő, hogy Victor már a Vonzás szabályaiban is kifejezetten érdeklődött a zene iránt, valamint, hogy a Glamorámában kiderül, hogy egy zenekarban is játszik (Ellisnek szintén volt egy bandája). A szöveg egyébiránt annyira gazdag az idézetekben, hogy valószínüleg nincs olvasó, aki ne tudna néhányat (vagy legalább egyet) azonnal beazonosítani, ez különösen akkor igaz, ha eredetiben olvassuk a regényt, ezért az alábbiakban így hivatkozom rájuk néhány példán keresztül.

Már rögtön a regény elején Victor az egyik ismerösétől a „Take your passion and make it happen" (Ellis 1998, 18) szavakkal búcsúzik, mely Irene Cara What a feeling jól ismert dalából származik, s mely egyben a Flashdance címü film betétdala is. De szintén jó példa a „Hakuna matata” (Ellis 1998, 123) kijelentés is Victortól, mely minden olvasónak ugyanazt idézi fel: Elton John dalát és az Oroszlánkirály címü Disney-filmet. Itt is jól látható, hogy a Glamoráma az olvasás során egy olyan folyamatot hoz létre, melyben az olvasó aktívan köti össze a szöveget más szövegekkel és médiumokkal, ezzel együtt különleges kulturális környezetet teremt, mely jóval túlmutat magán a könyv médiumán. Úgy tűnhet, hogy Ellis a zene segítségével, a vizuális és akusztikai elemek keverésével próbálja hitelesíteni a történet filmes ábrázolását. Nem meglepő tehát, hogy például Geoff King is azzal érvel, hogy a ,hang fontos szerepet játszik az építkezési folyamatban, fokozza a folytonossági hatást, illetve megalapozza a valós/hiteles képet és a modalitást" (King 2005, 53). Szerinte a zene és a hang megerősíti az elbeszélés által felépitett képeket: a filmes narratíva, amelyben a főszereplő él, hitelesebbé válik, amikor felcsendül egy-egy zenei mü. Ez tulajdonképpen így is müködik mindaddig, amíg észre nem vesszük, hogy bizonyos citátumoknak egyáltalán semmi köze az adott szituációhoz, nem illeszkedik az adott kontextushoz, és egyáltalán nem erősíti meg az elbeszélés által konstruált képeket. Nem világos például, hogy Victor miért épp a „Shine on, you crazy diamond" (Ellis 1998, 94) Pink Floyd-sorral válaszol egy zenekari vita során, vagy ahogy az sem, amikor az MTV interjút készít vele, és az egyik kérdésre, ami felidegesíti, miért a Nirvana Smells Like Teen Spirit címü dalát idézi: „A mulatto, an albino, a mosquito, my libido” (Ellis 1998, 142). A sor még jócskán folytatható lenne. Néha tehát nemcsak maga az idézés módja és ideje tűnik értelmetlennek, hanem maga az idézet tartalma is.

Deisler Szilvia kiválóan foglalja össze a jelenséget: „Az említett dalok nemcsak akkor váltanak ki elidegenítő hatást, amikor dalszövegükkel szándékos kontrasztot képeznek a leírt jelenettel, de azzal is, hogy legtöbbször egyáltalán nem kötődnek a cselekményhez, és inkább egy MTV-válogatás véletlenszerüen kiragadott dalainak összességeként hatnak, amennyiben nem tudatosítjuk a már említett szöveg 
szintjén előforduló további kapcsolatrendszereket” (Deisler 2018, 134). S hogy mindez ne legyen elég, a szövegben az is elöfordul, hogy Victor egy teljes párbeszéd során kizárólag idézetekkel, dalszövegekkel válaszol és vitatkozik (Ellis 1998, 107). Megjelenik itt a Turn the beat around, Vicki Sue Robinson 1976-os slágere, majd szintén ebböl a dalból származik a következő sor, a „love to hear percussion”, ezután a KC \& The Sunshine Band „that's the way, uh-huh uh-huh, I like it, uh-huh uh-huh" sorával válaszol, majd a „Muskrat Suzy, Muskrat Sa-a-am” követi, ami Willis Alan Ramsey „Muskrat Candlelight” dala, végül a „London, Paris, New York, Munich, everybody talk about - pop music" mondat Robin Scott Pop Muzik címü slágeréből származik, aki „M” néven vált ismertté. Bár a magyar fordítás itt is kiválóan idézi a slágereket (Ellis 2016b, 156), eredetiben olvasva könnyebben, gyorsabban felismerhetök ezek a dalok. Később aztán az is kiderül, hogy hősünk nem az egyedüli, aki a párbeszédek során dalszövegeket idéz, sőt gyakran elöfordul, hogy idézetre idézettel válaszolnak, ami paradox módon kifejezetten idegesíti Victort (Ellis 1998, 126). Ezek az intermediális hivatkozások így tehát a popzenén keresztül alakítják Victor nyelvi kifejezökészségét.

Fontos azonban hangsúlyozni, hogy Victor intermediális természetű elbeszélése nemcsak azt a funkciót tölti be, hogy olvasóját esztétikai tapasztalatban részesíti (azáltal, hogy azonosítja, felismeri az egyes citátumokat és utalásokat), hanem abban is érdekelt, hogy „az intermediális referenciák révén a médiumok mibenlétét, konvergálását az értelmezés tétjévé avassa" (Fodor - L. Varga 2012, 164). Ennek eredményeként a Glamoráma vizuális és akusztikus jelenetei elhomályositják a valóságot, amelyet fokoz a különböző érzékszervek egyidejü aktiválása által okozott zavar. Másképp fogalmazva: a filmes valóság és a regény valósága közé szorulva az olvasók ki vannak téve Victor vizuális és akusztikai hallucinációinak is. A zürzavar, amelyet a médiumok összemosása okoz, a regény globális és alárendelt szintjén egyaránt jelen van, a szójátékok, a dalok, citátumok és a nyelvhasználat egyéb kétértelműségei pedig nyilvánvaló példák a mediatizált nyelv működésére. A regény bebizonyította azt is, hogy a médiumok nem szeparáltan jelentkeznek, hanem folyamatosan kapcsolódnak más-más médiumokhoz, illetve azok technikai feltételeihez.

Amikor filmet nézünk, gyakran vágyunk arra, hogy mi is a kép részeseivé váljunk: miközben átéljük a jelenetet, gondolatban akár eggyé is válunk kedvenc hösünkkel. Victorral tulajdonképpen pont ez történik a regény során. A különböző médiumokon keresztül áramló képeket és üzeneteket elnyeli és integrálja saját életébe, beszédébe. A regény legvégén Victor az üres bárban üldögélve egy festményt bámul, amibe teljesen belemerül, elveszik a látványban és végül azt látjuk, hogy Victor is a kép részévé válik és megjelennek az ,igazi csillagok” (Ellis 2016b, 655). De vajon az égiteströl van-e szó vagy inkább egy filmcsillag születéséröl? Tagadhatatlan, hogy Victor valami újat is tanult, valami változáson ment keresztül a regény során. Ellis elbeszélöi közül ő az egyetlen, aki ezt elmondhatja magáról. Ez egyébként a tudatos szimbólumhasználatból is kiderül, amit a szerző is megerősített egy interjú alkalmával:

Amikor írni kezdtem ezt a könyvet, tudtam, hogy az első szó a „pettyek” lesz, az utolsó szó pedig a „hegy”; úgy éreztem, a könyv folyamatos fejlődés egyik szótól a másikig. 
Érzelmileg Victor sok mindent megtanul mind a külvilágról, mind saját magáról, ami úgy gondolom, azzal függhet össze, hogy én magam is derülátóbban tekintek az életemre, mint korábban. (Clarke 2004, 59)

Akár úgy is tűnhet, hogy a Glamoráma világa az olvasás során egyre valódibbá válik. A történet végét itt párhuzamba vonhatjuk azzal, ahogy elindult. A regény elején egy sokatmondó párbeszéd zajlik a pettyekröl:

Victor, senki sem tagadja a pettyek létezését - mondja Peyton óvatosan. - De bele kell helyezned a pettyeket egy... ööö... szóval egy bizonyos kontextusba.

[...]

Úgy értem, mindenki úgy tesz, mintha az lenne a kérdés, hogy azok a pettyek valóságosak-e, vagy az egész csak valami illúzió. Szerintem meg rohadtul valóságosak. A valóság illúzió, bébi - mondja JD nyugtatólag. - A valóság csak egy illúzió, Victor. (Ellis 2016b, 17-19)

A pettyek, melyeket Victor nem lát egy kontextusban, egyrészt arra utalhatnak, hogy az összképet, amit Victor próbál összerakni, pettyek zavarják, másrészt pedig a képpontokat, a pixeleket is érthetjük alatta. Tudjuk, hogy egy digitális kép adatokból, számokból és pixelekből áll. Egy ilyen kép értelmezéséhez ezeket az alkotóelemeket egységesen kell tudnunk kezelni („,belehelyezni egy bizonyos kontextusba”), máskülönben az egész látvány egy „,szétesett világ” lesz csupán. És talán pont erről van itt szó, hiszen a fiktív világ „,pixeleire” bomlik fel a Glamorámában, a „valóság csak egy illúzió” és felmerül a gyanú, hogy ebben a mediatizált univerzumban talán csak a csillagok ,igaziak”.

A csillagok igaziak.

A jövö az a hegy. (Ellis 2016b, 655)

\section{Irodalom}

Baelo-Allué, Sonia (2007): Intermedility in Literature: Bret Easton Ellis and the MTV Novel. In: Maddalena Pennacchia Punzi (ed.): Literary Intermediality. Bern: Peter Lang AG, 145-162.

Baelo-Allué, Sonia (2011): "It's Really Me": Intermediality and Constructed Identities in Glamorama. In: Naomi Mandel (ed.): Bret Easton Ellis. American Psycho, Glamorama, Lunar Park. London - New York: Continuum, 84-97.

Clarke, Jaime (2004): Interjú Bret Easton Ellis-szel. Ford. Gyuris Gergely. Fosszília, 4., 36-67.

Colby, Georgina (2011): Cloning the Nineties: Cultural Amnesia, Terrorism, and Contempoary Iconoclasm in Glamorama. In: Uö: Bret Easton Ellis. Underwriting the Contemporary. New York: Palgrave Macmillan, 95-129.

Deisler Szilvia (2018): Puzzle-hatás. Dunaszerdahely: NAP Kiadó. 
Ellis, Bret Easton (1991): American Psycho. London: Picador.

Ellis, Bret Easton (1998): Glamorama. London: Picador.

Ellis, Bret Easton (2016a): Amerikai Psycho. Ford. Bart István. Budapest: Európa Könyvkiadó.

Ellis, Bret Easton (2016b): Glamoráma. Ford. M. Nagy Miklós. Budapest: Európa Könyvkiadó.

Fodor Péter - L. Varga Péter (2012): Az eltünés könyvei. Bret Easton Ellis. Budapest: Palimpszeszt - Prae.

H. Nagy Péter (2007): Hibridek. Dunaszerdahely: NAP Kiadó.

King, Geoff (2005): "Just Like a Movie"?: 9/11 and Hollywood Spectacle. In: Uö: The Spectacle of the Real: From Hollywood to 'Reality' TV and Beyond. Bristol, UK: Intellect Books, 47-57.

Kulcsár Szabó Ernő (2000): Ex Libris. Élet és irodalom, 2000. augusztus 25., 17.

Molnár Gábor Tamás (2005): Világirodalom a modernség után. Budapest: Hatágú Síp Alapitvány.

Rajewsky, Irina O. (2005): Intermediality, Intertextuality, and Remediation: A Literary Perspective on Intermediality. Intermédialités 6., 43-64.

Schmid, David (2011): The Unusual Suspects: Celebrity, Conspiracy, and Objective Violence in Glamorama. In: Naomi Mandel (ed.): Bret Easton Ellis. American Psycho, Glamorama, Lunar Park. London - New York: Continuum, 69-83. 